\title{
NOTES ON MATERIAL CULTURE
}

Native Dwellings and Ceremonial Structures $\quad$ I05

Indians as Basket Collectors 106

Tulare Basketry 110

The Basketry of the Mono $\quad$ II

Indian Hats $\quad$ I23

$\begin{array}{ll}\text { Plates } 25-48 & 125\end{array}$

COMPARATIVE RECORDS

Pinart's Tcholovone Vocabulary I33

Words for Tobacco and Pipe $\quad$ I39

Shoshonean Tribal Names $\quad$ I49

Tribal Names of the Tuleyome $\quad 175$

California Mission Baptismal Records $\quad$ I88

Bibliography 227

Index 231

\section{ILLUSTRATIONS}

MAP

Boundaries of the Tuleyome

Figures in Text

Elevation and cross section of Pomo dance house 30

Plan of Pomo dance house $\quad 31$

Sketch of roof structure of Pomo dance house 32

Flicker-feather headbands $\quad 34$

Ko-too-mut pole $\quad 78$

Ko-too-mut basket design $\quad 85$

Plates

Plates I-24 97

Plates $24-48 \quad I 25$ 